\title{
THE DETERMINING FACTORS OF FINANCIAL INCLUSION IN TURKEY
}

\author{
DOI: 10.17261/Pressacademia.2020.1290 \\ JEFA- V.7-ISS.3-2020(3)-p.223-235
}

\section{Hasmet Sarigul}

Istanbul Esenyurt University, Faculty of Business and Management Sciences, Istanbul, Turkey. hasmetsar@yahoo.com , ORCID: 0000-0001-7262-6668

Date Received: July 6, 2020

Date Accepted: September 5, 2020

To cite this document

Sarigul, H., (2020). The determining factors of financial inclusion in Turkey. Journal of Economics, Finance and Accounting (JEFA), V.7(3), p.223-235.

Permanent link to this document: http://doi.org/10.17261/Pressacademia.2020.1290

Copyright: Published by PressAcademia and limited licensed re-use rights only.

\section{ABSTRACT}

Purpose- The purpose of this study is to investigate the impacts of GDP per capita, unemployment rate, cost of living index, gini coefficient, median age, urbanization rate, total length of railways and roads, number of road motor vehicles, number of mobile phone subscribers, number of broadband internet subscribers, literacy rate and mean years of schooling on financial inclusion in Turkey..

Methodology- The models were estimated using the Johansen Cointegration method, and the causality relationships between the variables were tested with the Granger and Toda-Yamamoto approaches.

Findings- The Johansen approach findings reveal a significantly positive long-run co-movement between financial inclusion and GDP per capita, urbanization and a significantly negative long-run co-movement between unemployment, cost of living and financial inclusion. However, according to the results of the Granger method, there has been no causality relationship between the variables. The results of the Toda-Yamamoto causality test are consistent with the results of the Granger causality test, except fort the urbanization variable which has been found to have a short term casual effect on financial inclusion in the Toda-Yamamoto test.

Conclusion- The significant relationship between the level of financial inclusion and the rate of urbanization in the short and long run reveals that the increase in the level of urbanization causes individuals to access financial institutions more easly and be able to use more financial products in Turkey.

Keywords: Financial inclusion, time series, cointegration, causality, Turkey.

JEL Codes: C32, D14, G20

\section{INTRODUCTION}

Although financial inclusion is a widely discussed issue in finance literature, it does not have a common definition due to its multidimensional nature and various different approaches. However, it refers to the situation in where individuals can effectively access financial services and use financial products. Broadly, financial inclusion can be defined as the existence of a financial system that enables weaker and disadvantaged individuals of the society to have access to and be able to use financial products. While financial inclusion is to make financial services accessible and usable by the majority of the society, financial exclusion emphasizes the situation that prevents low income and disadvantaged individuals of society from having access and being able to use these financial services.

The factors affecting the level of financial inclusion may arise from supply and demand. Socio-economic factors and individuals' perceptions and attitudes on financial issues are supply-side factors. Lack of financial services, in other words financial exclusion, may occur voluntarily or involuntarily. Voluntary financial exclusion may be due to cultural or religious factors, or due to the indifference individuals may have towards financial services. Involuntarily exclusion includes obstacles such as not having trust in financial institutions, inappropriate prices, maturity of the product, product design that does not meet the needs, and failure to meet other eligibility criteria. The demand-side factors include socio-economic and technological factors such as income, education level, age, gender, transportation and telecommunication facilities (Abel, Mutandwa and Le Roux, 2018; Demirgüc-Kunt, Klapper, Singer and Van Oudheusden, 2015; Dittus and Klein, 2011; European Commission, 2008).

Economic factors are considered as one of the major determinants of financial inclusion. Many studies reveal that financial inclusion is positively related to economic development and the factors such as unemployment, poverty, and income 
inequality negatively impact the access to and use of financial services (Bittencourt 2012; Jeanneney and Kpodar 2011; Pal and Vaidya 2011; Clarke, Xu and Zou 2006). Socio-demographic factors can play an important role in strengthening financial inclusion. In societies where socio-demographic factors do not support financial inclusion, individuals are more likely to avoid using financial services, fewer people have bank accounts, and cash transactions widespread. These situations impact the demand side of financial inclusion (Cull, Ehrbeck and Holle, 2014; Dev, 2006). Another factor that influences financial inclusion is technology. The financial services industry is one of the sectors that supports technological innovation and also puts them into practice. Innovative financial service companies create and develop digital platforms to make their customers' daily transactions more cost-effective, faster and easier. Technological developments reduce the need to travel long distances, and ensure the efficient distribution of financial products and services. Electronic payment systems, mobile banking, and other fintech applications are becoming more widespread, so financial inclusion is able to improve with a new and wideranging stakeholder group from the digital world (Global Partnership for Financial Inclusion 2014; De Koker and Jentzsch 2013; Duncombe and Boateng 2009).

Due to the belief of its positive impacts on financial systems and the economy, financial inclusion issues have recently been gaining more attention among researchers, policy makers and practitioners. In many countries, studies have been carried out by financial institutions, governments and non-governmental organizations to develop strategies that may enable low-income and disadvantaged groups to be better included in the financial system. These efforts have also been supported by international financial and economic institutions such as the International Monetary Fund and the World Bank (DemirgücKunt, Beck and Honohan, 2008; Kempson, Atkinson and Pilley, 2004; Leyshon and Thrift, 1995). In Turkey, "Financial Access, Financial Education, Consumer Financial Protection Strategy and Action Plans" were put into practice in 2014 aiming to strengthen the demand side of financial inclusion by considering the indicators of financial access and the financial infrastructure (Prime Ministry of Turkey, 2014). Within this scope, a total of 55 action plans have been determined in the fields of financial education and financial consumer protection. In addition, many public institutions, autonomous institutions and non-governmental organizations have been identified for collaboration. Understanding the linkage between financial inclusion and economic, social, demographic and other issues will be beneficial to policy makers and practitioners in their efforts to strengthen financial inclusion in the country. However, there have been few academic studies conducted on financial inclusion within Turkey. To fill this gap, this study aims to contribute to the understanding of the economic, technological, social and demographic drivers of financial inclusion in Turkey. In this context, the study has researched the impacts of some selected variables in the fields of economy, population, demography, transportation, information society and education on financial inclusion in Turkey.

The study has been structured as follows; the review of the literature on financial inclusion has been presented in the second part following the introduction, part three gives the details of the data used in the research and methodology, the results of the econometric models applied in the research have been presented in the fourth section, and part five presents the conclusion.

\section{LITERATURE REVIEW}

The issue of financial inclusion, which was first discussed in England in 1997 with the view that development should be spread to different areas, has been the interest of various international and national institutions, researchers and practitioners. Early studies focus more on the definition and nature of financial inclusion (Dev, 2006). Later, the studies on developing financial inclusion measurement methods and measuring, monitoring, and analysing financial inclusion in different countries has become frequent (Demirgüc-Kunt, Klapper, Singer and Van Oudheusden, 2015; Gündüz and Özyıldırım, 2019; Bayero, 2015; Fungáčová and Weill, 2015; Cámara and Tuesta, 2014; Yorulmaz 2013; Chakravarty and Pal, 2013; World Bank, 2013; Gupte, Venkataramani and Gupta, 2012; Sarma, 2008; Kempson, Atkinson and Pilley, 2004). In this continuous process, the literature has expanded with studies examining the relationship between financial inclusion and economic, social, demographic, geographical, technological and other variables.

Whether development and economic growth causes any increase in financial inclusion levels is one of the issues discussed extensively in the literature. Raza, Tang, Rubab and Wen (2019) have conducted a meta-analysis study in Pakistan. A significant and positive relationship between financial inclusion and economic development has been found by the authors which reveals that an increase in the level of financial inclusion may improve economic development. Van, Vo, Nguyen and Vo (2019) have applied a panel econometric model to estimate if financial inclusion impacts economic growth or not. The findings support a positive relationship between economic growth and financial inclusion consistent with many previous studies. In addition, it has been determined that the relationship is stronger in the countries where the income and financial inclusion levels are lower. The results of the panel data study conducted by Kim, Yu and Hassan (2018), using the data of the Organization of Islamic Cooperation's 55-member countries, also reveal that financial inclusion has a positive impact on economic growth. The linear cointegration test results of Sethi and Sethy (2018) together with the data of India for the period from 1975 to 2014 show that there has been a long-run relationship between economic growth and financial inclusion. Both 
demand and supply side improvements in financial inclusion positively impacts economic growth. Shailesh and Ragabiruntha (2018) have collected data through a structured questionnaire and have established a model to determine which factors led economic development through financial inclusion in Tamil Nadu. According to the major findings of their study; financial literature, online banking and understanding banking services are the drivers of financial inclusion and economic development can be led by financial inclusion. Another study which reveals a positive long-run relationship between economic growth and financial inclusion has been conducted by Sethi and Acharya (2018) with data from 31 countries spanning the period 2004-2011.

Some of the studies conducted on the issues of financial inclusion have explored the relationship between financial inclusion and economic welfare indicators - two which are widely used are GDP per capita and income inequality. The findings of the research of Sha'bana, Girardone and Sarkisyan (2020) indicate that there has been a significant positive relationship between GDP per capita and financial inclusion. Jung and Cha (2020) who explored the long-run relationship between financial income inequality and development have found that at the provincial level in China, financial deepening makes inequality worse. According to Ginevicius, Dudzeviciute, Schieg and Peleckis (2019) the highest level of financial development has been demonstrated by the countries which have middle GDP per capita indicators. According to Nanda (2017) the level of financial inclusion seems to reflect a movement in tandem with the extent of per capita income and the extent of socio-economic development. The empirical analysis of Sarma and Pais (2011) reveals that per capita gross domestic product, urbanisation, adult literacy and income inequality are important factors in explaining the level of financial inclusion in a country. In addition to these, the other factors which have a positive impact in increasing financial level are electronic and physical connectivity and information availability, indicated by road networks, telephone and internet usage.

Saifullahi, Özdeşer and Çavuşoğlu (2019) have examined the finance-welfare linkage of Nigerian households in rural areas. The findings have shown financial inclusion has a strong positive impact on the welfare of households. However, the decomposition analysis results have shown that middle-income and high-income households benefit more from the increased level of financial inclusion compared to low-income ones. Zhang and Posso (2019) have researched the impact of financial inclusion on the income of households by using data covering more than 6,200 Chinese households and have found a strong and positive impact of financial inclusion on household income. In contrast with the studies of Sani Ibrahim, Ozdeser and Cavusoglu conducted in Nigeria, the Chinese study by Zhang and Pooso has shown that low-income households benefit more from financial inclusion than high-level and mid-level income households. Anwar and Amrullah (2017) have found in their research that financial inclusion can reduce poverty by affecting the overall economy, but it can increase inequality at the same time. The results of Kim's research (2016), which uses data on the 40 countries in the European Union and OECD between 2004 and 2011, reveal that financial inclusion causes an improvement on the relationship between economic growth and income inequality. Income inequality reduction by means of financial inclusion transforms the negative relationship to a positive relationship between income inequality and economic growth. This transformation trend is stronger in high-fragile countries than in low-fragile countries.

It is widely accepted in the literature that the developments in information and communication technologies are important factors in enlarging financial inclusion. According to Chatterjee (2020), financial inclusion can improve the per capita growth both individually or collectively with information and communication technologies. Musabegovic, Ozer, Djukovic and Jovanovic (2019) have investigated the relationship between the usage of new technologies and GDP per capita. The results of their study reveal a significantly positive relationship between GPD per capita and the usage of smartphones in financial transactions and payment processes. Patwardhan, Singleton and Schmitz (2018) have indicated that taking advantage of the convenience provided by electronic transactions, integrating mobile phones into the payments system, and using technology for turning high-cost operations into self-service or automated processes significantly caused reductions in the cost and expanded access to financial services.

Some studies in the literature investigating the determinants of financial inclusion based on different factors apart from those mentioned above.

Susilowati and Leonnard (2019) have investigated the factors using the microdata from global findex 2014. The findings of their binary logistic regression have indicated that there are significant and positive relationships between financial inclusion and the constraints to financial services, motivation to use financial services and sources of loans. By using the World Bank's 2017 Global Findex Database, Özşuca (2019) analysed the factors which might cause gender differences in using financial products and services. Outputs of the study indicate that disparity in financial inclusion is significantly related to employment. Age and higher education have also been found to be contributing factors to the financial inclusion gap. Alhassan, Li, Reddy and Duppati's (2019) findings indicate that the level of financial inclusion is positively related to higher education and higher incomes, and has been negatively affected by religious tensions and unemployment. Szopinski (2019) has investigated the reasons for individuals who chose to be unbanked in Poland and has found the major factors for being unbanked are lower income, lower levels of education, younger age, lack of trust in commercial banks and living in small towns or cities. Using the 
World Bank's 2017 Global Financial Inclusion database Chu (2019) has applied probit estimation for different measures of financial inclusion. Outputs of the study reveal that being a man, more educated, richer, employed, and older than a certain age increases the likelihood of access to formal financial services. Bozkurt, Karakuş and Yıldız (2018) have examined the possible factors which might generate changes in financial inclusion levels by using 2011 - 2014 period data of 120 countries. The results of their study have revealed that the major factors in the change in financial inclusion are social, banking and political issues. Evans and Osi (2017) have applied a Bayesian VAR model with the World Bank Development Indicators datasets covering the 2005 - 2014 period of 15 African countries. The results have shown that the effects of credit supply, literacy, internet users and servers, and broad money on financial inclusion are positive and significant. In their research in which they used the data of thirty OECD countries, Van der Werff, Hogarth and Peach (2013) have determined that high trust in financial institutions and government causes an increase in the level of financial inclusion.

\section{DATA AND VARIABLE DESCRIPTION}

The widely used indicators in measuring financial inclusion are access to and use of financial services and products, and quality measures. Access indicators reflect how deep financial access is. Usage indicators measure how adults use financial services. Quality measures specify the compliance level of financial products and services to the needs of customers, the range of options available to customers, and the awareness level and understanding of adults regarding financial services and products (World Bank, 2013). According to Kempson, Atkinson and Pilley (2004), a good financial inclusion measure should be simple, practical, as multidimensional as possible, and should include comparable indicators.

In this study, four access and four usage indicators are used to calculate financial inclusion, taking into account the accessibility of data. Financial access indicators reveal the geographical and demographic penetration of service points. Financial usage indicators show how widespread its use is and how affordable it is (Table 1). Financial inclusion data is obtained from The Central Bank of the Republic of Turkey (TCMB), Banking Regulation and Supervision Agency of Turkey (BDDK), The Banks Association of Turkey (TBB), Participation Banks Association of Turkey (TKBB), The Interbank Card Centre (BKM), and Turkish Statistical Institute (TurkStat).

\begin{tabular}{|c|c|c|c|}
\hline & Code & Indicator & Definition \\
\hline \multirow{4}{*}{ 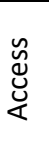 } & $B R P G$ & Branch penetration (geographical) & Branch number per $1,000 \mathrm{~km}^{2}$ \\
\hline & $B R P D$ & Branch penetration (demographic) & Branch number per 100,000 population ( +15 years age) \\
\hline & ATMG & ATM penetration (geographical) & ATM number per $1,000 \mathrm{~km}^{2}$ \\
\hline & ATMD & ATM penetration (demographic) & ATM number per 100,000 population (+15 years age) \\
\hline \multirow{4}{*}{ 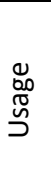 } & $\angle A P P$ & Loan account penetration (prevalence) & Loan account number s per 1,000 population (+15 years age) \\
\hline & LIRA & Loan / income ratio (affordability) & The ratio of average loan amount to GDP per capita \\
\hline & $D A P P$ & Deposit account penetration (prevalence) & Deposit account number per 1,000 population ( +15 years age) \\
\hline & DIRA & Deposit / Income Rate (affordability) & $\begin{array}{l}\text { The ratio of the average deposit account amount to GDP per } \\
\text { capita }\end{array}$ \\
\hline
\end{tabular}

ATM: Automated teller machine

Higher geographical measurements reveal that the distance is shorter and easier to access to financial services. Per capita branch and ATM distributions show the demographic spread of financial services and measure how many customers a bank and ATM serve. Higher values mean fewer people per branch or ATM and easier access. Deposit and loan account numbers per 100,000 +15 age population indicate the prevalence of the use of financial services. The ratio of average loan and deposit amount to GDP shows the affordability of financial services by individuals. Higher rates indicate that financial services are mostly available to upper income groups (Işık, 2011). Descriptive statistics of financial inclusion indicators used in the study are presented in Table 2.

\begin{tabular}{lccrrr}
\hline \multicolumn{1}{l}{ Table 2: Descriptive Statistics of Financial Inclusion Indicators } & & & \\
\hline BRPG & $n$ & Mean & SD & Min. & Max. \\
BRPD & 22 & 11.43 & 2.82 & 7.85 & 15.48 \\
ATMG & 22 & 12.47 & 2.06 & 9.33 & 15.61 \\
ATMD & 22 & 32.83 & 20.02 & 8.6 & 66.29 \\
LAPP & 22 & 34.62 & 18.38 & 11.16 & 63.34 \\
LIRA & 22 & 120.88 & 85.49 & 15.48 & 254.78 \\
DAPP & 22 & 0.53 & 0.14 & 0.31 & 0.74 \\
DIRA & 22 & $1,593.23$ & 579.03 & 775.95 & $2,727.65$ \\
\end{tabular}


Individual interpretation of the indicators may lead to misleading results. Therefore, the Financial Inclusion Index (FIITR) has been created in order to provide information about the indicators of financial inclusion as a single value and to measure its relationship to numerous variables.

In order to be easily calculable and to produce comparable information, an index has been created for each dimension by accepting 1997 as the base year, and then the Financial Inclusion Index (FIITR) was calculated by taking the arithmetic mean of the two.

FIITR $=\frac{\sum \frac{d_{t}}{d_{0}} \times 100}{N}$

$\left(d_{t}\right.$ : value of financial inclusion dimension in the relevant year, $d_{t}$ : value of financial inclusion dimension in base year, $N$ : number of observed dimensions)

The variables whose impacts on financial inclusion have been investigated include the fields of economy, population, demography, transportation, information society and education. Table 3 gives definitions and Table 4 presents the descriptive statistics of variables.

\begin{tabular}{|c|c|c|c|c|}
\hline Field & Code & Time Period & Source & Definitions \\
\hline \multirow{4}{*}{$\begin{array}{l}\text { हे } \\
\text { O } \\
\text { ठ }\end{array}$} & GDPPC & $1997-2018$ & TurkStat & Per capita gross domestic product in purchasers' value. \\
\hline & UNEMP & $1997-2018$ & TurkStat & $\begin{array}{l}\text { Unemployment rate among non-institutional population by } \\
\text { labour force status ( } 15-65 \text { years of age). }\end{array}$ \\
\hline & COLIN & $1997-2018$ & TCMB, ITO & $\begin{array}{l}\text { Cost of living index (foodstuffs, heating and lighting articles, } \\
\text { clothing and house furniture, house rent and maintenance } \\
\text { and miscellaneous). }\end{array}$ \\
\hline & GINIC & $1997-2018$ & TurkStat & Gini coefficient by equalized household disposable income. \\
\hline \multirow{4}{*}{ 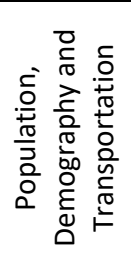 } & MEDAG & $1997-2018$ & TurkStat & $\begin{array}{l}\text { Median age obtained from population censuses and address } \\
\text { based population registration system.. }\end{array}$ \\
\hline & URBAN & $1997-2018$ & TurkStat & $\begin{array}{l}\text { The share of population living in province and district } \\
\text { centres. }\end{array}$ \\
\hline & RWROD & $1997-2018$ & TurkStat & Length of railways and roads. \\
\hline & VHCLE & $1997-2018$ & TurkStat & $\begin{array}{l}\text { Number of road motor vehicles excluding road construction } \\
\text { machineries, work machineries and tractors. }\end{array}$ \\
\hline \multirow{4}{*}{ 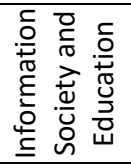 } & $\mathrm{MOBPH}$ & $1997-2018$ & TurkStat, BTK & Number of mobile phone subscribers. \\
\hline & INTRN & $1997-2018$ & TurkStat, BTK & Number of broadband internet subscribers. \\
\hline & LITER & $1997-2018$ & TurkStat & Literacy rate (6 years of age and over). \\
\hline & $S C H O L$ & $1997-2018$ & TurkStat & Mean years of schooling. \\
\hline
\end{tabular}

* ITO: Istanbul Chamber of Commerce, BTK: Information and Communication Technologies Authority of Turkey

\begin{tabular}{lrrrr}
\hline \multicolumn{1}{l}{ Table 5: Descriptive Statistics of Variables } & & & \\
\hline Variable & Mean & SD. & Min. \\
\hline FIITR & 2.68 & 1.33 & 1.00 & 4.69 \\
GDPPC & $8,092.69$ & $3,323.37$ & $3,084.39$ & $12,480.37$ \\
UNEMP & 9.77 & 1.66 & 6.40 & 12.90 \\
COLIN & $4,179.84$ & $1,388.66$ & $5,960.34$ & $2,007.77$ \\
GINIC & 0.42 & 0.03 & 0.38 & 0.52 \\
MEDAG & 28.39 & 2.29 & 24.70 & 32.02 \\
URBAN & 75.37 & 11.46 & 60.77 & 92.50 \\
RWROD & $138,181.36$ & $4,100.88$ & $133,229.00$ & $146,347.00$ \\
VHCLE & $13,739,364.64$ & $5,171,641.28$ & $6,863,462.00$ & $22,865,921.00$ \\
MOBPH & $48,300,537.59$ & $26,618,589.16$ & $1,483,149.00$ & $80,117,999.00$ \\
INTRN & $19,328,421.59$ & $24,609,698.04$ & $75,000.00$ & $74,500,089.00$ \\
LITER & 89.47 & 5.37 & 82.00 & 96.42 \\
SCHOL & 6.59 & 0.98 & 5.10 & 8.00 \\
\hline
\end{tabular}




\subsection{Unit Root Tests}

Augmented Dicky Fuller (ADF), Phillips-Perron (PP), and Kwiatkowski-Phillips-Schmidt-Shin (KPSS) unit root tests are used to analyse stationarity properties of variables.

Augmented Dicky Fuller (ADF), Phillips-Perron (PP), and Kwiatkowski-Phillips-Schmidt-Shin (KPSS) unit root tests are used to analyse stationarity properties of variables.

ADF test is an extended application version of the DF (Dickey and Fuller, 1981). DF tests whether $\gamma=0$ in the data of model.

$y_{t}=\alpha+\beta t+\gamma y_{t-1}+\varepsilon_{t}$

where $y_{t}$ represents the interest variable, $t$ represents the time index, $\gamma$ represents a coefficient, and $\varepsilon$ is the error term. The regression equation is written as

$\Delta \mathrm{y}_{t}=y_{t}-y_{t-1}=\alpha+\beta t+\gamma y_{t-1}+\varepsilon_{t}$

where $\Delta$ represents the first difference operator. By writing in this way, a linear regression $\Delta \mathrm{y}_{t}$ against $t$ and $y_{t-1}$ can be applied and it can be tested whether $\gamma$ has any difference from 0. $\gamma=0$ indicates a random walk process. If not and $-1<1+$ $\gamma<1$, the process is accepted as stationary.

The major problem with this method is that the Dickey-Fuller method is not effective if $\varepsilon$ in an autoregressive model is auto correlated (Maddala and Kim 1999). To solve this problem, ADF unit root test has been proposed. By adding $\Delta \mathrm{y}_{t-p}$ to the equation, the ADF approach enables high order autoregressive processes. But still the $\gamma=0$ equation is tested.

$\Delta y_{t}=\alpha+\beta t+\gamma y_{t-1}+\delta_{1} \Delta y_{t-1}+\delta_{2} \Delta y_{t-2} \ldots+\varepsilon_{t}$

The PP test (Phillips and Perron, 1988) is a non-parametric approach in which the selection of serial correlation level is not required. Unlike the ADF method, it rather takes the prediction scheme similar with DF method, but in this model the statistic is corrected for autocorrelations and heteroscedasticity. The last unit root test, which will be applied to the time series used in our study to improve the finite sample properties of the ADF and PP tests is the KPSS test in which the null hypothesis is examined under the assumption that an observable time series is stationary around a deterministic trend. For the KPSS approach, the null hypothesis is that the series is stationary.

\subsection{Cointegration}

In the research, Johansen approach is used for testing cointegration (Johansen and Juselius, 1990; Johansen, 1988). Vector error correction (VEC) representation is as follows in Johansen cointegration approach.

$\Delta x_{t}=\sum_{i-1}^{k-1} \delta_{i} \Delta x_{t-1}+\Pi x_{t-1}+\mu+\varepsilon_{t}$

where $\Delta x_{t}$ pt comprise a null vector I(0) of $n x$ series. The parameter $\mu$ is the deterministic component composed of the constant, trend, structural break, and seasonality; $\delta_{i}$ represents the short run parameter. The long-run relationship is captured by the matrix, defined as, where $x$ is stationary if a cointegration relationship exists and the matrix $\Pi$ has a reduced rank of ( $r$ ): $0<r<n$ (Thong, Ankamah-Yeboah, Julia Bronnmann, Nielsen, Roth and Schulze-Ehlers, 2020).

In Johansen Method, the maximum likelihood of the matrix is estimated assuming that the error variables are distributed normally. The Johansen tests are also known as maximum eigenvalue and trace tests.

$L R\left(r_{0}, r_{0}+1\right)=-T \operatorname{In}\left(1-\lambda_{r o+1}\right)$

The trace approach examines whether the rank of the matrix $\Pi$ is $r_{0}$. The alternative hypothesis is that $r_{0}<\operatorname{rank}(\Pi) \leq n$, where $n$ represents the possible cointegrating vectors' maximum number.

$\operatorname{LR}\left(r_{0, n}\right)=-T \sum_{i=r_{0+1}}^{n} \operatorname{In}\left(1-\lambda_{i}\right)$

where $\operatorname{LR}\left(r_{0, n}\right)$ represents the statistic of a likelihood test if ratio statistic rank is $(\Pi)=r$ or $(\Pi) \leq n$. 


\subsection{Causality Tests}

Finally, causality relationships between the variables will be tested by using the Granger and Toda-Yamamoto methods. Granger causality is a widely used approach in times series to examine the causality relationship between two variables by following a "bottom up" procedure.

$Y=\sum_{i=1}^{t} \alpha_{i} X_{t-i}+\sum_{i=1}^{t} \beta_{i} Y_{t-1}+\mu$

$X=\sum_{i=1}^{t} \lambda_{i} X_{t-1}+\sum_{i=1}^{t} \lambda Y_{t-1}+v$

where, $X$ does not, Granger causes $Y$ in the Eq. (8) and $Y$ does not, Granger causes $X$ in the Eq. (9) are null hypothesis' $\left(h_{0}\right)$. The rejection of null hypothesis $\left(h_{1}\right)$ reveals Granger-cause where $\mu$ and $v$ are correlated.

Toda-Yamamoto, the second method used to reveal the causality relationships between the variables in the research, is not sensitive to cointegration properties and is feasible for stationary or non-stationary VAR models. In this method, preliminary information such as whether the variables contain unit root or the number of cointegration vectors is not needed. In TodaYamamoto method, constraint tests such as Wald likelihood ratio and LaGrange multiplier are investigated with a valid Wald statistic (an asymptotic $x^{2}$ distribution), regardless of the order of integration of the variable (Toda and Yamamoto 1995).

$Y_{t}=\alpha_{i}+\sum_{i=1}^{k+d} \gamma_{1 i} Y_{t-i}+\sum_{i=1}^{k+d} \gamma_{2 i} Y_{t-1}+\varepsilon_{y t}$

$X_{t}=\alpha_{2}+\sum_{i=1}^{k+d} \delta_{1 i} Y_{t-i}+\sum_{i=1}^{k+d} \delta_{2 i} Y_{t-1}+\varepsilon_{x t}$

where $k$ represents the optimal lag order, $d$ represents the maximum order of integration of the series, and $\varepsilon_{y t}$ and $\varepsilon_{x t}$ represent error terms.

\section{RESULTS}

In this study, the impacts of the variables regarding economy, population, demography, transportation, information society and education issues on financial inclusion is examined using annual data from Turkey over the 1997 - 2018 period. To explain these impacts, the following vector auto regression (VAR) models have been formulated.

FIITR $_{t}=\alpha_{0}+\alpha_{1}$ GDPPC $_{t}+\alpha_{2}$ UNEMP $_{t}+\alpha_{3} \operatorname{COLIN}_{t}+\alpha_{4}$ GINIC $_{t}+\varepsilon_{t}$

where; FIIT is the dependent variable representing Financial Inclusion Index. GDPPC is the gross domestic product per capita, UNEMP is the unemployment rate, COLIN represents the cost of living index, GINIC represents the Gini coefficient, $\alpha_{0}$ represents the constant term, $\alpha_{1}, \alpha_{2}, \alpha_{3}, \alpha_{4}$ represents the coefficients of the exogenous variables, $t$ represents time and $\varepsilon$ is the stochastic term.

FIITR $_{t}=\alpha_{0}+\alpha_{1} M E D A G_{t}+\alpha_{2} \operatorname{URBAN}_{t}+\alpha_{3} R W R O D_{t}+\alpha_{4} \operatorname{VHCLE}_{t}+\varepsilon_{t}$

where; MEDAG is the median age, URBAN is the urbanization rate, RWROD is the sum of the length of railways and roads, $V H C L E$ is the number of road motor vehicles.

FIITR $_{t}=\alpha_{0}+\alpha_{1}$ MOBPH $_{t}+\alpha_{2}$ INTRN $_{t}+\alpha_{3}$ LITER $_{t}+\alpha_{4}$ SCHOL $_{t}+\varepsilon_{t}$

where; MOBPH represents the number of mobile phone subscribers, INTRN represents the number of broadband internet subscribers, LITER represents the literacy rate, SCHOL represents mean years of schooling.

In the first stage of the research, the stationarity of the series was examined at 0.05 significance level by applying unit root tests.

\begin{tabular}{|c|c|c|c|c|c|c|c|}
\hline \multirow[b]{2}{*}{ Series } & & \multicolumn{2}{|r|}{ ADF } & \multicolumn{2}{|r|}{$\mathrm{PP}$} & \multicolumn{2}{|r|}{ KPSS } \\
\hline & & Level & 1st difference & Level & 1st Difference & Level & 1st Difference \\
\hline \multirow{2}{*}{ FIITR } & Test & -0.070 & -3.100 & 0.199 & -3.065 & 0.635 & 0.190 \\
\hline & $\mathrm{Cv}$ & -3.021 & -3.021 & -3.012 & -3.021 & 0.463 & 0.463 \\
\hline \multirow{2}{*}{$G D P P C$} & Test & -1.469 & -4.016 & -1.466 & -4.026 & 0.564 & 0.279 \\
\hline & $\mathrm{Cv}$ & -3.012 & -3.021 & -3.012 & -3.021 & 0.463 & 0.463 \\
\hline \multirow{2}{*}{ UNEMP } & Test & -2.252 & -3.855 & -2.252 & -4.402 & 0.393 & 0.092 \\
\hline & $\mathrm{Cv}$ & -3.012 & -3.040 & -3.012 & -3.021 & 0.463 & 0.463 \\
\hline \multirow{2}{*}{ COLIN } & Test & -1.981 & -3.262 & -1.376 & -3.307 & 0.447 & 0.381 \\
\hline & $\mathrm{Cv}$ & -3.040 & -3.021 & -3.012 & -3.021 & 0.463 & 0.463 \\
\hline GINIC & Test & -1.616 & -4.057 & -2.082 & -7.094 & 0.442 & 0.114 \\
\hline
\end{tabular}




\begin{tabular}{|c|c|c|c|c|c|c|c|}
\hline \multirow{3}{*}{ MEDAG } & $\mathrm{Cv}$ & -3.021 & -3.066 & -3.012 & -3.021 & 0.463 & 0.463 \\
\hline & Test & -1.004 & -4.287 & -0.659 & -3.490 & 0.662 & 0.135 \\
\hline & $\mathrm{Cv}$ & -3.021 & -3.030 & -3.012 & -3.021 & 0.463 & 0.463 \\
\hline \multirow{2}{*}{ URBAN } & Test & -0.343 & -4.619 & -0.268 & -4.633 & 0.621 & 0.112 \\
\hline & $\mathrm{CV}$ & -3.012 & -3.021 & -3.012 & -3.021 & 0.463 & 0.463 \\
\hline \multirow{2}{*}{$R W O D$} & Test & 2.809 & -2.432 & 2.487 & -2.402 & 0.654 & 0.441 \\
\hline & $\mathrm{Cv}$ & -3.012 & -3.021 & -3.012 & -3.021 & 0.463 & 0.463 \\
\hline \multirow{2}{*}{ VHCLE } & Test & 3.591 & -2.348 & 3.930 & -2.262 & 0.637 & 0.576 \\
\hline & $\mathrm{Cv}$ & -3.012 & -3.021 & -3.012 & -3.021 & 0.463 & 0.463 \\
\hline \multirow{2}{*}{ МOBPH } & Test & -2.098 & -2.774 & -1.784 & -1.167 & 0.625 & 0.290 \\
\hline & $\mathrm{Cv}$ & -3.030 & -3.030 & -3.012 & -3.021 & 0.463 & 0.463 \\
\hline \multirow{2}{*}{ INTRN } & Test & 5.018 & -1.638 & 4.382 & -1.491 & 0.569 & 0.541 \\
\hline & $\mathrm{Cv}$ & -3.012 & -3.021 & -3.012 & -3.021 & 0.463 & 0.463 \\
\hline \multirow{2}{*}{ LITER } & Test & -1.611 & -1.508 & -0.535 & -2.842 & 0.638 & 0.146 \\
\hline & $\mathrm{Cv}$ & -3.030 & -3.030 & -3.012 & -3.021 & 0.463 & 0.463 \\
\hline \multirow{2}{*}{$\mathrm{SCHOL}$} & Test & -1.109 & -3.775 & -1.094 & -3.775 & 0.629 & 0.184 \\
\hline & $\mathrm{Cv}$ & -3.012 & -3.021 & -3.012 & -3.021 & 0.463 & 0.463 \\
\hline
\end{tabular}

where $\mathrm{Cv}$ is critical value.

In ADF and PP tests, the basic hypothesis is "there is a unit root in the series", and in the KPSS test, "there is no unit root in the series". It is seen that FIITR, GDPPC, UNEMP, COLIN, GINIC, MEDAG, URBAN, LITER and SCHOL series appear to be first difference stationary while VHCLE and INTRN series are non-stationary in all tests. RWOD and MOBPH series are first difference stationary in KPSS test, but non-stationary in ADF and PP tests (Table 6). After excluding the non-stationary series from the scope of the research, the Eq. (13) and Eq. (14) are combined and the VAR models to be used in the research are formulated as follows.

$$
\begin{aligned}
& \text { FIITR }_{t}=\alpha_{0}+\alpha_{1} \text { GDPPC }_{t}+\alpha_{2} \text { UNEMP }_{t}+\alpha_{3} \text { COLIN }_{t}+\alpha_{4} \text { GINIC }_{t}+\varepsilon_{t} \\
& \text { FIITR }_{t}=\alpha_{0}+\alpha_{1} \text { MEDAG }_{t}+\alpha_{2} \text { URBAN }_{t}+\alpha_{3} \text { LITER }_{t}+\alpha_{4} \text { SCHOL }_{t}+\varepsilon_{t}
\end{aligned}
$$

In the next stage, long-term relationships between the variables are tested with the Johansen Cointegration framework.

\begin{tabular}{|c|c|c|c|c|c|c|c|}
\hline & Lag & LogL & LR & FPE & AIC & SC & $\mathrm{HQ}$ \\
\hline \multirow{3}{*}{ 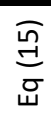 } & 0 & -262.789 & - & 1201902. & 28.18831 & 28.43685 & 28.23038 \\
\hline & 1 & -244.704 & 24.74786 & 2781676 & 28.91621 & 30.40743 & 29.16859 \\
\hline & 2 & -170.2 & $62.74054 *$ & $30796.12^{*}$ & $23.70522 *$ & 26.43913* & $24.16791^{*}$ \\
\hline \multirow{3}{*}{$\begin{array}{l}\widetilde{\sigma} \\
\stackrel{-}{\sigma} \\
\bar{\varpi}\end{array}$} & 0 & -15.2905 & - & 5.8306* & 2.135843 & $2.384380^{*}$ & 2.177906 \\
\hline & 1 & -1.63421 & 18.68757 & $2.15 e-05$ & 3.329917 & 4.821136 & 3.582290 \\
\hline & 2 & 40.22946 & 35.25362 & $7.39 \mathrm{e}-06$ & $1.554794 *$ & 4.288696 & $2.017478 *$ \\
\hline
\end{tabular}
Akaike Information Criterion (AIC) is used to determine optimal lag length.

* indicates the optimal lag length at 0,05 level.

LR: Sequential modified LR test statistic, FPE: Final prediction error, AIC: Akaike information criterion, SC: Schwarz information criterion, HQ: Hannan-Quinn information criterion.

Johansen Cointegration test results reveal that there are three cointegration equations for the Eq. (15) and one cointegration equation for the Eq. (16). The findings of the trace and maximum eigenvalue tests are consistent with each other. In order to

\begin{tabular}{|c|c|c|c|c|c|}
\hline & Hypotesized no of cointegrating equation(s) & $\lambda_{\max }$ & $\lambda_{\text {trace }}$ & Critical Value & Probability** \\
\hline \multirow{4}{*}{$\begin{array}{l}\stackrel{\Xi}{\beth} \\
\stackrel{\dot{\sigma}}{\square}\end{array}$} & None* & 0.993319 & 164.1922 & 69.81889 & 0.0000 \\
\hline & At most $1^{*}$ & 0.817202 & 69.03100 & 47.85613 & 0.0002 \\
\hline & At most $2^{*}$ & 0.714999 & 36.74285 & 29.79707 & 0.0067 \\
\hline & At most 3 & 0.361508 & 12.89287 & 15.49471 & 0.1188 \\
\hline \multirow{2}{*}{$\dot{\breve{w}}$} & None* & 0.965375 & 116.3989 & 69.81889 & 0.0000 \\
\hline & At most 1 & 0.793487 & 52.49834 & 47.85613 & 0.0172 \\
\hline
\end{tabular}
predict the models by the Johansen method, the number of delays was determined as two according to the AIC (Table 7). 


\begin{tabular}{lllll} 
At most 2 & 0.481698 & 22.52793 & 29.79707 & 0.2700 \\
At most 3 & 0.348576 & 10.04117 & 15.49471 & 0.2776 \\
\hline
\end{tabular}

* the hypothesis is rejected at the level of 0.05 significance

** MacKinnon-Haug-Michelis (1999) $p$ values.

$\lambda_{\text {max }}:$ Maximum Eigen statistic, $\lambda_{\text {trace }}:$ Trace statistic,

The long-term equilibrium models estimated using the Johansen method are as follows.

FIITR $_{t}=6.109+0.001$ GDPPC $_{t}+-45.769$ UNEMP $_{t}+-7.406$ COLIN $_{t}+1.607$ GINIC $_{t}$

$\begin{array}{llll}(0.023) & (0.000) & (0.047) & (0.000)\end{array}$

FIITR $_{t}=6.841+-6.191 M E D A G_{t}+0.174 U R B A N_{t}+-1.736$ LITER $_{t}+7.11 S C H O L_{t}$

$\begin{array}{llll}(0.846) & (0.664) & (0.001) & (0.129)\end{array}$

It is seen that the $t$ values of the GDPPC, UNEMP, COLIN variables in Eq. (15) and URBAN variable in Eq. (16) are statistically significant at 0.05 level. The results of Johansen's cointegration test suggests significant and positive long-run co-movement between financial inclusion and GDP per capita, urbanization and a significantly negative long-run co-movement between financial inclusion, unemployment, and cost of living.

In the next stage, The Granger causality test has been performed to examine the causal relationship between variables. The optimal lag length determined by VAR for both models (Eq. 15 and Eq. 16) is two. The results of the Granger tests reveal no short-term causal relationships between variables (Table 9).

\begin{tabular}{lccc}
\hline \multicolumn{2}{l}{ Table 9: Granger Causality Test Results } & & \\
\hline Direction of Causality & F statistic & probability** & Decision \\
\hline GDPPC $\rightarrow$ FIITR & 1.3344 & 0.2948 & $h_{0}$ \\
FIITR $\rightarrow$ GDPPC & 0.9065 & 0.4264 & $h_{0}$ \\
UNEMP $\rightarrow$ FIITR & 0.4731 & 0.6327 & $h_{0}$ \\
FIITR $\rightarrow$ UNEMP & 1.0332 & 0.3815 & $h_{0}$ \\
COLIN $\rightarrow$ FIITR & 1.6679 & 0.2241 & $h_{0}$ \\
FIITR $\rightarrow$ COLIN & 2.2697 & 0.1400 & $h_{0}$ \\
URBAN $\rightarrow$ FIITR & 0.6338 & 0.5451 & $h_{0}$ \\
FIITR $\rightarrow$ URBAN & 0.3582 & 0.7052 & $h_{0}$ \\
\hline
\end{tabular}

where $h_{0}$ : no causal effect of $X$ on $Y, h_{1}$ : causal effect of $X$ on $Y$

Arrows point the direction of causality

Short-term causality relationships were also tested using the Toda-Yamamoto method with the length of $2+1=3(P+$ $\left.d_{\text {max }}\right)$. The findings of the Toda-Yamamoto test are consistent with the results of Granger causality test apart from URBAN $\rightarrow$ FIITR hypothesis which indicates that there is a one-way causal relationship running from urbanization level to financial inclusion (Table 10).

\begin{tabular}{|c|c|c|c|}
\hline Direction of Causality & Test statistic & $p$ value & Decision \\
\hline GDPPC $\rightarrow$ FIITR & 1.7922 & 0.4082 & $h_{0}$ \\
\hline FIITR $\rightarrow$ GDPPC & 1.4678 & 0.4800 & $h_{0}$ \\
\hline UNEMP $\rightarrow$ FIITR & 3.1729 & 0.2046 & $h_{0}$ \\
\hline FIITR $\rightarrow$ UNEMP & 1.9542 & 0.3764 & $h_{0}$ \\
\hline COLIN $\rightarrow$ FIITR & 4.5629 & 0.1021 & $h_{0}$ \\
\hline FIITR $\rightarrow$ COLIN & 2.6839 & 0.2613 & $h_{0}$ \\
\hline URBAN $\rightarrow$ FIITR & 6.0656 & 0.0482 & $h_{1}$ \\
\hline FIITR $\rightarrow$ URBAN & 0.5549 & 0.7577 & $h_{0}$ \\
\hline
\end{tabular}

where $h_{0}$ : no causal effect of $X$ on $Y, h_{1}$ : causal effect of $X$ on $Y$

Arrows point the direction of causality

\section{CONCLUSION}

In this study, the factors which might have an impact on financial inclusion in Turkey during the period of 1997 - 2018 were examined. In this context, firstly, the financial inclusion index, which consists of four access and four usage dimensions, was created. The variables whose effect on financial inclusion would be investigated were determined through the fields of 
economy, population, demography, transportation, information society and education, and three regression models were created. GDP per capita, unemployment rate, cost of living index, Gini coefficient, median age, urbanization rate, total length of railways and roads, number of road motor vehicles, number of mobile phone subscribers, number of broadband internet subscribers, literacy rate and mean years of schooling as the independent variables.

The series was first difference stationary except from total length of railways and roads, number of road motor vehicles, number of mobile phone subscribers and number of broadband internet subscribers' series which were all non-stationary. Non-stationary variables were excluded from analysis and models were combined. For the estimation of the models, the Johansen Cointegration method was applied and causality relationships between the variables were tested with Granger and Toda-Yamamoto approaches.

Consistent with many studies demonstrating financial inclusion is positively and significantly related to GDP per capita, it was expected to find that GDP per capita has a positive impact on financial inclusion since increases in income may cause people to demand more financial services. Findings obtained by the Johansen approach suggests a significantly positive long-run comovement between financial inclusion and GDP per capita. However, outputs of Granger and Toda-Yamamoto causality tests reveal there is no causality relationship in short-run between GDP per capita and financial inclusion in Turkey.

Unlike GDP per capita, it was expected that financial inclusion levels would decrease as national unemployment levels increase and therefore a negative relationship between unemployment and financial inclusion may appear. On the examination of cointegration test results it is seen that there is a significantly negative long-run co-movement between financial inclusion and unemployment in Turkey. Similar to the GDP per capita, the results of Granger and Toda-Yamamoto causality tests reveal that there is no significant causal relationship between unemployment and financial inclusion in Turkey in the short-run.

Increases in the cost of living were expected to impact savings rates negatively and thus financial inclusion. However, financial inclusion also has access to and use of loan dimensions. Increases in living costs may also cause an increase in the demand for consumer loans. Findings obtained by the Johansen approach suggests a significantly positive long-run co-movement between financial inclusion and cost of living. However, no significant short-term causality effect is determined between two variables.

Financial inclusion is a key enabler in reducing poverty and boosting prosperity (World Bank, 2018). Although decreases in the level of inequality were expected to cause an increase in financial inclusion, no significant long-run cointegration and no short-run causality effect has been determined between the Gini coefficient and the financial inclusion in Turkey.

It is widely accepted that the aging of a population has considerable impacts on financial markets because of the increase in savings rates and the demand for investment funds (Bosworth, Bryant and Burtless, 2004). On the other hand, unbanked adults may be of a younger age. The increases in the median age was expected to cause increases in financial inclusion. However, the outputs of the research show that there is no significant relationship between median age and financial inclusion in Turkey in the short and long run.

It is generally stated that the urbanization process leads to the growth of various infrastructural facilities as well as helps in promoting entrepreneurship and industrial growth. Therefore, high rate of urbanization was expected to give a boost to the financial sector resulting in a higher level of financial inclusion. The outputs of Johansen's cointegration test reveal significant and positive long-run co-movement between urbanization rate and financial inclusion. In addition, urbanization rate variable is found to have a short-run causal effect on financial inclusion in the Toda-Yamamoto test. The significant relationship between the level of financial inclusion and urbanization rate in the short and long run reveals that the increase in the level of urbanization causes individuals to access financial institutions more easily and use more financial products in Turkey.

Although a higher literacy rate and mean years of schooling were expected to cause higher financial inclusion levels by providing more information and awareness about financial products, the results obtained from the research do not reveal significant relationship in the short and long-run between two variables.

\section{REFERENCES}

Abel, S., Mutandwa, L., \& Le Roux, P. (2018). A review of determinants of financial inclusion. International Journal of Economics and Financial Issues, 8(3): 1-8.

Alhassan, A., Li, L., Reddy, K., \& Duppatl, G. (2019). The relationship between political instability and financial inclusion: Evidence from Middle East and North Africa. International Journal of Finance and Economics, Early Access.

Anwar, A. I., \& Amrullah, A. (2017). Impact of financial inclusion towards poverty in Indonesia. Proceedings of The 2nd International Conference On Accounting, Management, and Economics (40): 407-410. 
Bayero, M. A. (2015). Effects of cashless economy policy on financial inclusion in Nigeria: An exploratory study. Procedia - Social and Behavioral Sciences, 172: 49-56.

Bittencourt, M. (2012). Financial development and economic growth in Latin America: Is Schumpeter right? Journal of Policy Modeling, 34(3): 341-355.

Bosworth, B., Bryant, R., \& Burtless, G. (2004). The impact of aging on financial markets and the economy: A Survey. Center for Retirement Research at Boston College.

Bozkurt, I., Karakuş, R., \& Yıldız, M. (2018). Spatial determinants of financial inclusion over time. Journal of International Development, 30: 1474-1504.

Cámara, N., \& Tuesta, D. (2014), Measuring financial inclusion: A muldimensional index. BBVA Research Paper 14/26.

Chakravarty, S. R., \& Pal, R. (2013). Financial inclusion in India: An axiomatic approach. Journal of Policy Modeling, $35(5)$ : 813-837.

Chatterjee, A. (2020). Financial inclusion, information and communication technology diffusion, and economic growth: A panel data analysis. Information Technology for Development, Early Access.

Chu L. (2019). Determinants of financial inclusions: Comparing high, middle, and low-income countries. Economics Bulletin, 39(2): 14491457.

Clarke, G., Xu, L. U. \& Zou, H. F. (2006). Finance and income inequality: What does the data tell us? Southern Economic Journal, 72(3): 578596.

Cull R., Tilman, E., \& Holle, N. (2014). Financial inclusion and development: Recent impact evidence. CGAP Focus Note, 92. Retrieved from https://www.Cgap.Org/Sites/Default/Files/Focusnote-Financial-Inclusion-And-Development-April-2014.Pdf.

De Koker, L. \& Jentzsch, N. (2013). Financial inclusion and financial integrity: Aligned incentives? World Development, 44: $267-280$.

Demirgüç-Kunt, A., Klapper, I., Singer, D. \& Van Oudheusden, P. (2015). Measuring financial inclusion around the world. World Bank Policy Research Working Paper 7255. Retrieved from http://Documents.Worldbank.Org/Curated/En/187761468179367706/The-Global-FindexDatabase-2014-Measuring-Financial-Inclusion-Around-The-World.

Demirgüç-Kunt, A., Beck, T., \& Honohan, P. (2008), Finance for all? Policies and pitfalls in expanding access, World Bank, Washington DC. Dev, S. M. (2006). Financial inclusion: Issues and challenges. Economic and Political Weekly, 41: 4310-4313.

Dickey, D. \& Fuller, W. A. (1981). Likelihood ratio statistics for autoregressive time series with a unit root. Econometrica, 49: $1057-1072$.

Dittus, P., \& Klein, M. U. (2011). On harnessing the potential of financial Inclusion. BIS Working Paper No. 347. Retrieved from https://www.bis.org/publ/work347.pdf

Duncombe, R., \& Boateng, R. (2009). Mobile phones and financial services in developing countries: A review of concepts, methods, issues, evidence and future research directions. Third World Quarterly, 30(7): 1237-1258

European Commission (2008). Financial services provision and prevention of financial exclusion. Retrieved from https://www.FiCompass.Eu/Publication/Other-Resources/Financial-Services-Provision-And-Prevention-Financial-Exclusion.

Evans, O., \& Alenoghena, R. (2017). Financial inclusion and GDP per capita in Africa: A Bayesian VAR model. Journal of Economics and Sustainable Development, 8(18), pp. 44-57.

Fungáčová, Z. \& Weill, L. (2015). Understanding Financial Inclusion in China. China Economic Review, 34C: $196-206$.

Ginevicius, R., Dudzevičiūtè, G., Schieg, M., \& Peleckis, K. (2019). The inter-linkages between financial and economic development in the European Union Countries. Economic Research-Ekonomska Istraživanja, 32(1): 3309-3326.

Global Partnership for Financial Inclusion. (2014). Digital financial inclusion and the implications for customers, regulators, supervisors and standard. Retrieved from https://www.Gpfi.Org/Publications/Digital-Financial-Inclusion-And-Implications-Customers-RegulatorsSupervisors-And-Standard-Setting.

Gupte, R., Venkataramani, B., \& Gupta, D. (2012). Computation of financial inclusion index for India. Procedia-Social and Behavioral Sciences, 37: 133-149.

Gündüz, M., \& Özyildirim, Y. (2019). Türkiye'de Illere Göre Finansal Kapsayıcılık Endeksinin Ölçülmesi. Bankacılar, 111: 52-70.

Huterski, R., Huterska, S. A., Lapińska, J., \& Zdunek-Rosa, E. (2020). The problem of savings exclusion and gross savings in the New European Union member states. Entrepreneurship and Sustainability Issues, 7(3): 2470-2480.

Işık, İ. (2011). Dünyada ve Türkiye'de finansal hizmetlere erişim ve finansal eğitim. Türkiye Cumhuriyet Merkez Bankası, Ankara.

Jeanneney, S. G., \& Kpodar, K. (2011). Financial development and poverty reduction: Can there be a benefit without a cost? The Journal of Development Studies, 47(1): 143-163. 
Johansen, S. (1988). Statistical Analysis of Cointegration Vectors. Journal of Economic Dynamics and Control, 12(2-3): 231-254.

Johansen, S., \& Juselius, K. (1990). Maximum likelihood estimation and inference on cointegration - with applications to the demand for money. Oxford Bulletin of Economics and Statistics, 52(2): 169-210.

Jung, S. M., \& Cha, H. E. (2020). Financial Development and Income Inequality: Evidence from China. Journal of the Asia Pacific Economy, Early Access.

Kempson, E., Atkinson, A., \& Odile Pilley, O. (2004). Policy level response to financial exclusion in developed economies: Lessons for developing countries. Report of Personal Finance Research Centre, University of Bristol, Bristol. Retrieved from http://www.Ggy.Bris.Ac.Uk/Pfrc/Reports/Policy_Response_To_Fin_Exc_EK_0506.Pdf.

Kim, D. W., Yu, J. S., \& Hassan, M. K. (2018). Financial inclusion and economic growth in OIC Countries. Research in International Business and Finance, 43: 1-14.

Kim J. H. (2016), A study on the effect of financial inclusion on the relationship between income inequality and economic growth. Emerging Markets Finance and Trade, 52(2): 1-15.

Leyshon, A., \& Nigel Thrif, N. (1995). Geographies of financial exclusion: financial abandonment in Britain and The United States. Transactions of the Institute of British Geographers, 20(3): 312-341.

Maddala, G. S., \& Kim, I. M. (1999). Unit roots, cointegration, and structural change (themes in modern econometrics), Cambridge University Press, Cambridge-UK.

Musabegovic, I., Özer, M., Duković, S., \& Jovanović, S. (2019). Influence of financial technology (FINTECH) on financial industry. Economics of Agriculture, 66(4): 1003-1021.

Nanda K. (2017). Bank led financial inclusion and socio economic development: The case of Indian States. Pacific Business Review International, 10(4): 39-49.

Özşuca, E. A. (2019). Gender gap in financial inclusion: Evidence from MENA. Economics and Bussiness Letters, 8(4): $199-208$.

Pal, R., \& Vaidya, R. (2011). Outreach of banking services across Indian States: 1981-2007 converging or diverging? In DM Nachane (Ed.). India Development Report, pp. 116-129.

Patwardhan, A., Singleton, K., \& Schmitz, K. (2018). Financial inclusion in the digital age. International Finance Corporation - Creditease Stanford Graduate School of Business.

Phillips, Peter C. B. \& Perron, P. (1988). Testing for a unit root in time series regression. Biometrica, 75(2): 335-346.

Prime Ministry of Turkey. (2014). Financial access, financial education, financial consumer protection strategy and action plans. Official Gazette of Turkey No. 29021.

Raza, M., Tang, J., Rubab, S. \& Wen, X. (2019). Determining the nexus between financial inclusion and economic development in Pakistan. Journal of Money Laundering Control, 22(2): 195-209.

Saifullahi, S. I., Özdeşer, H., \& Çavuşoğlu, B. (2019). Financial Inclusion as A Pathway to Welfare Enhancement and Income Equality: MicroLevel Evidence from Nigeria. Development South Africa, 36(3): 390-407.

Sarma, M., \& Pais, J. (2011). Financial inclusion and development. Journal of International Development, 23(5): 613-628.

Sarma, M. (2008). Index of financial inclusion. Indian Council for Research on International Economic Relations. New Delhi Working Papers 215.

Sethi, D., \& Acharya, D. (2018). Financial inclusion and economic growth linkage: Some cross country evidence. Journal of Financial Economic Policy, 10(3): 369-385.

Sethi, D., \& Sethy, S. K. (2018). Financial inclusion matters for economic growth in India. International Journal of Social Economics, 46(1): 132151.

Sha'bana, M., Girardone, C., \& Sarkisyan, A. (2020). Cross-country variation in financial inclusion: A global perspective. The European Journal of Finance, 26(4-5): 319-340.

Shailesh, R., \& Ragabiruntha, E. (2018). Financial inclusion and socioeconomic development: Gaps and solution. International Journal of Social Economics, 45(7): 1122-1140.

Susilowati, E. \& Leonnard, L. (2019). Factors influence financial inclusion: Evidence from Indonesian micro data. Etikonomi, 18(1): $121-132$.

Szopinski, T. (2019). Who is unbanked? Evidence from Poland. Contemporary Economcis, 13(4): 417-426.

Thong, N. T., Ankamah-Yeboah, I., Bronnmann, J., Nielsen, M., Roth, E., \& Birgit Schulze-Ehlers, B. (2020). Price transmission in the pangasius value chain from Vietnam to Germany. Aquaculture Reports, 16:1-7. 
Toda, H. Y., \& Yamamoto, T. (1995). Statistical inference in vector autoregressions with possibly integrated processes. Journal of Econometrics, 66(1-2): 225-250.

World Bank. (2018). New report analyses China's impressive trajectory toward universal financial inclusion. Retrieved from https://Openknowledge.Worldbank.Org/Handle/10986/29336.

World Bank. (2013). Global financial development report: Financial inclusion. World Bank Publications. Retrieved from http://Documents.Worldbank.Org/Curated/En/225251468330270218/Global-Financial-Development-Report-2014-Financial-Inclusion.

Van, L. T. H., Vo, A. T., Nguyen, N. T., \& Vo, D. H. (2019). Financial inclusion and economic growth: An international evidence. Emerging Markets Finance and Trade, Early Acess.

Van Der Werff, A. Hogarth, J. M., \& Nathanael D. Peach, N. D. (2013). A cross-country analysis of financial inclusion within the OECD. Consumer Interests Annual, 59: 1-12.

Yorulmaz R. (2013). Construction of A Regional Financial Inclusion Index in Turkey. BDDK Bankacılık ve Finansal Piyasalar, 7(1): 79-101.

Zhang Q., \& Posso, A. (2019). Thinking Inside the Box: A Closer Look at Financial Inclusion and Household Income. The Journal of Development Studies, 55(7): 1616-1631.

Zhu, B. S. \& He, J. (2018). Is The Development of China's Financial Inclusion Sustainable? Evidence from A Perspective of Balance. Sustainability, 10(4): pp.1-16. 